\title{
POLA DIALOG YANG TERBENTUK DALAM PEMBELAJARAN FISIKA PADA MATERI FLUIDA STATIS MELALUI TRANSCRIPT BASED LESSON ANALYSIS (TBLA)
}

\author{
Nurul Vidiya Wanni ${ }^{1}$, Erwina Oktavianty ${ }^{2}$, Haratua Tiur Maria $S^{3}$, \\ Reva Fauzi ${ }^{4}$ \\ ${ }^{1}$ Pendidikan Fisika FKIP Universitas Tanjungpura, Pontianak \\ ${ }^{2}$ Pendidikan Fisika FKIP Universitas Tanjungpura, Pontianak \\ ${ }^{3}$ Pendidikan Fisika FKIP Universitas Tanjungpura, Pontianak \\ ${ }^{4}$ SMA Negeri 3, Pontianak
}

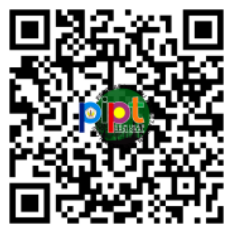

Email korespondensi : erwina.oktavianty@fkip.untan.ac.id

\begin{abstract}
Abstrak
The study was conducted to analyze the dialogue patterns of the physics learning process on static fluid material using Transcript Based Lesson Analysis (TBLA) in SMA Negeri 3 Pontianak. The study uses qualitative research methods in the form of descriptive research. The study used a purposive sampling technique to select the sample so that class XI IPA 5 was chosen with 38 students. The research instrument was an observation sheet (field notes). The technique of data collection was in the form of documentation and observation. The first data analysis was interpreting the learning process into a full verbal transcript obtained from audio and video recording, then analyzing the appropriate dialogue pattern. Based on the data analysis, the form of dialogue pattern learning in cycle 1 was a two-way communication pattern with a teacher speech average percentage of $7.70 \%$ and students' speech average percentage of $7.70 \%$, which indicated a balance between teachers and students. While in cycle 2, classically also used a two-way communication with a teacher speech average percentage of $8.34 \%$ and students' speech average percentage of $8.33 \%$. It indicated that the teacher and students are equally active. Then, in cycle 2 , there was a three-way communication with a teacher's average percentage of $1.13 \%$ and students' speech average percentage of $1.74 \%$. There was a reciprocal relationship between teachers and students, but students tend to be more active. The teacher can use the analytical method using Transcript Based Lesson Analysis (TBLA) to analyze teaching and learning processes in the classroom.
\end{abstract}

Kata kunci:Learning Dialogue Pattern, Static Fluid, Transcript Based Lesson Analysis (TBLA)

\section{PENDAHULUAN}

Fisika merupakan salah satu mata pelajaran wajib di dalam struktur kurikulum sekolah menengah atas (SMA). Menurut Giancoli (2001), ilmu fisika adalah ilmu yang paling mendasar, karena mengatur perilaku dan struktur benda. Melalui pembelajaran fisika peserta didik diharapkan dapat mengembangkan kemampuan berfikir yang berguna untuk mengatasi masalah dalam kehidupan sehari-hari.

Sebagian besar pembelajaran fisika dilakukan dengan model pembelajaran konvensional yaitu dengan ceramah, sehingga peserta didik menjadi bosan, kurang semangat dalam mengikuti pembelajaran serta kurang aktif dalam pembelajaran. Sedangkan menurut standar nasional pendidikan khususnya pada standar proses pembelajaran itu diarahkan pada students center learning (SCL).

Adapun isi dari peraturan pemerintah No. 19 Tahun 2005 tentang standar proses yaitu proses pembelajaran pada satuan pendidikan diselenggarakan secara interaktif, inspiratif, menyenangkan, menantang, memotivasi peserta didik untuk berpartisipasi aktif, serta memberikan ruang yang cukup untuk memuat gagasan, kreativitas dan kebebasan yang cukup sesuai dengan kemampuan, minat dan perkembangan fisik serta psikologis peserta didik. 
Untuk menerapkan isi yang tertuang di dalam peraturan pemerintah tersebut tidak terlepas dari seorang guru yang berperan aktif dalam pembelajaran. Dimana guru berperan aktif dalam mengelola kelas agar suasana kelas menjadi nyaman untuk belajar. Menurut Zein (2016), peran guru dalam proses pembelajaran adalah sebagai koordinator lingkungan belajar dan sekaligus sebagai fasilitator pembelajaran. Proses pembelajaran dapat terjadi karena adanya interaksi antara guru dan peserta didik maupun sesama peserta didik.

Interaksi ini disebut juga sebagai dialog. Dialog pembelajaran adalah proses pertukaran ide atau pemikiran yang terjadi diantara guru dan peserta didik serta antara peserta didik dalam pembelajaran (Mercer \& Littleton, 2007). Dimana guru memberikan informasi kepada peserta didik yang kemudian mereka menanggapinya dengan menyalurkan pendapatnya. Selain itu peserta didik juga saling bertukar pendapat dan masing-masing peserta didik mendengarkan perkataan antar peserta didik kemudian memikirkannya secara mendalam (Sato, 2012).

Seperti yang kita ketahui bahwa realitanya guru di sekolah kurang tepat dalam memberikan pertanyaan yang dapat menstimulus peserta didik agar tidak menimbulkan jawaban peserta didik yang singkat serta dapat menjelaskan jawaban dengan jelas. Hal ini dibuktikan pada penelitian yang dilakukan oleh Davies et al (2017); Lehesvouri et al (2011); Viiri \& Saari (2006) yang menyatakan bahwa guru kurang memahami fungsi dialog di dalam pembelajaran yang menyebabkan pembentukan lingkungan belajar kurang efektif.

Berdasarkan hasil penelitian terdahulu yang dilakukan oleh Nusantara, Shibata \& Hendayana (dalam Hajar, 2019) yang menyatakan bahwa pembelajaran masih didominasi oleh penjelasan guru dan jawaban-jawaban peserta didik yang pendek secara bersamaan ditambah dengan ketergantungan peserta didik terhadap guru yang besar dalam pembelajaran.
Berdasarkan hasil wawancara dengan salah satu guru fisika di SMA Negeri 3 Pontianak menyatakan bahwa respon peserta didik di dalam kelas itu bagus, tetapi tidak semua peserta didik di dalam kelas tersebut antusias menyimak. Atau tanya jawab hanya sekitar 5 orang saja yang begitu dikasih kesempatan untuk menanyakan hal-hal yang belum dipahami mereka inisiatif sendiri bertanya. Pada tahun sebelumnya guru mengajar tiga kelas dan dua kelas tersebut peserta didiknya aktif sedangkan satu kelasnya lagi itu peserta didiknya pasif. Pasif dalam artian ketika disuruh maju atau menjawab soal mereka takut-takut. Sedangkan pada masa pandemi sekarang ini dengan semester yang baru pembelajaran yang dilakukan agak sedikit berbeda yaitu pembelajaran dilakukan secara daring menggunakan aplikasi Kaizala dimana pembelajarannya berlangsung lewat grup chat. Guru yang mengajar juga hanya dua kelas saja yaitu kelas XI IPA 5 dan XI IPA 6. Meskipun pembelajaran dilakukan secara daring, namun kedua kelas tersebut memberikan respon yang bagus juga. Dimana ketika disuruh mengerjakan soal mereka langsung mengerjakan, kemudian apabila ada yang belum dipahami mereka juga bertanya. Di dalam kegiatan belajar mengajar tersebut juga terjadi interaksi, namun tidak bisa melihat karakteristik masing-masing peserta didik.

Menurut Usman (dalam Djamarah, 2014), interaksi belajar mengajar juga sangat beraneka ragam coraknya, dimulai dari kegiatan yang didominasi oleh guru sampai kegiatan mandiri yang dilakukan oleh peserta didik. Hal ini bergantung pada keterampilan guru dalam mengelola kegiatan belajar mengajar tersebut. Salah satunya yaitu dengan menggunakan pola interaksi yang bervariasi dalam pembelajaran. Sehingga tidak menimbulkan kebosanan dan kejenuhan dalam belajar serta dapat menghidupkan suasana kelas demi keberhasilan peserta didik dalam mencapai tujuan (Usman dalam Djamarah, 2014) 
Untuk lebih meningkatkan kualitas dialog pembelajaran dapat dilakukan melalui pengembangan program profesionalisme guru yaitu lesson study. Menurut Supriatna (2018), melalui kegiatan lesson study guru dapat mengetahui bagaimana cara peserta didik belajar dan berfikir serta bagaimana cara memfasilitasi agar peserta didik secara optimal dapat belajar untuk memenuhi keperluan hidupnya di masa depan yang lebih baik. Agar kualitas lesson study dapat meningkat sesuai dengan apa yang diharapkan, maka perlu dilakukan analisis terhadap pembelajaran secara mendalam dengan cara observasi dan perekaman membuat transkrip pembelajaran yang kemudian menganalisisnya. Metode untuk menganalisis transkrip pembelajaran dikenal sebagai metode Transcript Based Lesson Analyis (TBLA) (Supriatna, 2018).

Menurut Matsubara (dalam Supriatna, 2018), analisis terhadap transkrip pembelajaran adalah perekaman, transkrip, protokol kata, artulukalsi protokol kata, dan hubungan artikulasi. Hasil dari analisis terhadap transkrip pembelajaran akan menjadi data penting tentang bagaimana peserta didik belajar dan upaya yang diharapkan untuk meningkatkan kualitas pembelajaran (Supriatna, 2018). Selain itu hasil dari analisis ini yang nantinya dapat dijadikan perbaikan untuk pembelajaran selanjutnya.

Berdasarkan uraian di atas, maka penelitian ini dilakukan untuk menganalisis pola dialog pembelajaran yang terbentuk pada materi fluida statis melalui Transcript Based Lesson Analysis (TBLA) di SMA Negeri 3 Pontianak.

Pengertian dialog itu sendiri ialah pertukaran ide antara satu sumber dengan sumber lainnya (Mercer \& Littleton, 2007). Dalam pembelajaran, dialog adalah pertukaran ide atau pendapat antara guru dan peserta didik serta peserta didik dengan peserta didik saat pembelajaran berlangsung. Selain itu teori yang digunakan untuk menganalisis dialog (percakapan) adalah teori implikatur percakapan yang dikemukakan oleh Paul Herbert Grice.
Menurut Grice (dalam Nurhayati, 2015) menyatakan bahwa ada seperangkat asumsi yang melingkupi dan mengatur kegiatan percakapan sebagai suatu tindakan berbahasa. Hal ini sejalan dengan pendapat yang dikemukakan oleh Purwanto dan Djeniah (dalam Saptani, 2015) yang menyatakan bahwa bahasa sebagai media komunikasi manusia diperoleh melalui pemerolehan juga pembelajaran, pada hakikatnya belajar bahasa adalah mencari tahu bagaimana menyampaikan, baik lisan maupun tulisan serta ekspresi. Selain itu, bahasa juga merupakan alat pedagogik utama guru.

Adapun manfaat dari pembelajaran dialogis dapat digunakan untuk mengidentifikasi dan mempromosikan bentuk interaksi yang memiliki hasil pendidikan yang paling bermanfaat (Mercer \& Dawes, 2014). Pada intinya adalah menegaskan bahwa perkembangan pembelajaran dan intelektual peserta didik akan menjadi lebih baik, setidaknya untuk beberapa waktu di kelas. Peserta didik didorong dan didukung untuk berperan aktif dan sewajarnya dalam melakukan diskusi di kelas (Mercer \& Dawes, 2014). Sejalan dengan hal itu tentu saja bergantung pada keterampilan seorang guru dalam mengelola kegiatan belajar mengajar tersebut. Oleh karena itu guru dapat menggunakan variasi pola interaksi dengan tujuan agar tidak menimbulkan kebosanan, kejenuhan, serta untuk menghidupkan suasana kelas (Sudjana \& Usman dalam Djamarah, 2014).

Menurut Hadiat (dalam Lisa, dkk, 2018) analisis interaksi merupakan rangkaian peristiwa yang spesifik antara guru dan peserta didik di dalam suatu proses belajarmengajar, diperoleh dengan cara direkam dan dicatat, sehingga bisa mendapatkan gambaran tentang pola komunikasi yang terjadi.

Ada beberapa pola komunikasi antara guru dengan peserta didik yang dikemukakan oleh Usman (dalam Djamarah, 2014) dalam proses pembelajaran diantaranya yaitu pola komunikasi satu arah, pola komunikasi dua arah, pola komunikasi 
tiga arah, pola komunikasi multi arah, dan pola komunikasi segala arah (melingkar) : 1) Pola komunikasi satu arah, menurut Sudjana (dalam Inah, 2015) komunikasi satu arah yaitu guru sebagai pemberi aksi dan peserta didik sebagai penerima aksi. 2) Pola komunikasi dua arah, menurut Usman (dalam Djamarah, 2014) yaitu ada balikan (feedback) bagi guru, tidak ada interaksi antar peserta didik. 3) Pola komunikasi tiga arah, yaitu ada balikan bagi guru, anak didik saling belajar satu-satu sama lain (Usman dalam Djamarah, 2014). Dimana guru dan peserta didik aktif, lalu antar peserta didik juga aktif. 4) Pola komunikasi multi arah, menurut Effendy (dalam Yohanah \& Setyawan, 2017) pola komunikasi multi arah yaitu proses komunikasi yang terjadi dalam satu kelompok yang lebih banyak dimana komunikator dan komunikan akan saling bertukar pikiran secara dialogis. 5) Pola komunikasi segala arah (melingkar), setiap peserta didik mendapat giliran untuk mengemukakan pendapat atau menjawab pertanyaan yang diajukan oleh guru, dan tidak diperbolehkan berpendapat atau menjawab sampai dua kali sebelum semua peserta didik mendapat giliran (Usman dalam Djamarah, 2014).

Untuk meningkatkan profesionalisme guru dalam mengajar yaitu dengan kegiatan lesson study. Menurut Hendayana (dalam Supriatna, 2018) lesson study merupakan kegiatan guru yang di dalamnya terdapat kegiatan merancang pembelajaran, melaksanakan pembelajaran, mengobservasi pembelajaran, serta melakukan kegiatan refleksi atas hasil observasi pembelajaran yang dilakukan. Sejumlah penelitian telah mendokumentasikan bahwa lesson study memberikan kontribusi untuk mengubah cara guru mengajar, meningkatkan profesional guru, meningkatkan belajar peserta didik dan membangun hubungan antara penelitian dan praktek (Huang, Takahashi \& Ponte, 2019).

Adapun siklus lesson study menurut Saito (2006) terdiri dari tiga tahap : Perencanaan (Plan), Pembelajaran terbuka (Do), dan Refleksi (See). Berikut penjabaran kegiatan setiap tahapannya : 1) Perencanaan, merupakan workshop persiapan yang diadakan masing-masing universitas setiap awal semester. Pesertanya terdiri dari guru IPA dan matematika di sekolah sasaran yang mengizinkan guru lain untuk menghadiri pelajaran mereka, serta anggota fakultas universitas yang bekerjasama dengan guru sekolah. Dalam sesi ini, mereka membahas metodologi pengajaran, termasuk semua bahan ajar dan LKS yang akan digunakan, serta perkiraan jadwal waktu selama satu semester. 2) Pelajaran terbuka, adalah tahap observasi di dalam kelas. Guru mengundang dosen pendamping dari universitas untuk mengamati pembelajaran. Adapun prosedur pembelajaran yang dilakukan adalah sebagai berikut : pelajaran dimulai dengan pendahuluan, kemudian dicek pengetahuan peserta didik tentang topik tersebut. Guru memberikan tugas kepada peserta didik yang bekerja dalam kelompok kecil. Berdasarkan hasil kegiatan tersebut, dilakukan diskusi kelas dan peserta didik serta guru menarik kesimpulan tentang topik mereka melalui pertukaran ide. 3) Refleksi, pada sesi ini para guru dan pengamat saling berbagi pandangan dan komentar. Para pengamat memberikan komentar dan memberikan masukan kepada para guru agar mereka dapat meningkatkan pembelajaran yang lebih baik di masa depan.

Pembelajaran dengan lesson study ini merupakan pembelajaran kolaboratif karena di dalam pembelajaran saling berkolaborasi dengan banyak orang. Menurut Nizar yang dikutip oleh Hosnan (dalam Primadiati \& Djukri, 2017) menyatakan bahwa collaborative learning adalah proses belajar kelompok yang setiap anggota menyumbangkan informasi, pengalaman, ide, sikap, pendapat, kemampuan, dan keterampilan yang dimilikinya untuk secara bersama-sama meningkatkan pemahaman semua anggota. Pembelajaran kolaboratif mengacu pada strategi untuk menyelesaikan tugas atau masalah secara bersama sehingga lebih cepat dan lebih baik dengan usaha yang minimal (Mahmudi, 2006). 
Adapun kelebihan dan kelemahan dalam pembelajaran kolaboratif menurut Raharjo (2013) : 1) Kelebihan, peserta didik belajar bermusyawarah, peserta didik belajar menghargai pendapat orang lain, dapat mengembangkan cara berpikir kritis dan rasional, dapat memupuk rasa kerja sama, serta adanya persaingan yang sehat. 2) Kelemahan, pendapat dan pertanyaan peserta didik dapat menyimpang dari topik, membutuhkan waktu yang cukup lama, adanya sifat-sifat pribadi yang ingin menonjolkan diri atau sebaliknya yang lemah merasa rendah diri dan selalu bergantung pada orang lain, serta kebulatan atau kesimpulan materi kadang sulit untuk dicapai.

Untuk melihat bagaimana pembelajaran di dalam kelas dan bagaimana cara mengatasi masalah yang ada di dalam kelas diperlukan analisis. Metode analisis ini adalah Transcript Based Lesson Analysis (TBLA). TBLA adalah metode analisis hasil penelitian dengan menggunakan transkrip hasil percakapan. Tahapan kegiatan dalam melakukan analisis terhadap transkrip pembelajaran menurut Matsubara (dalam Supriatna, 2018) adalah perekaman, transkrip, protokol kata, artikulasi protokol kata, dan hubungan artikulasi. Pada saat proses pembelajaran berlangsung, dilakukan perekaman audio dan video dengan menggunakan perekam untuk mengetahui bagaimana cara guru mengajar dan melibatkan peserta didik dalam pembelajaran. Setelah proses pembelajaran direkam melalui video pembelajaran maka ditranskip untuk diterjemahkan ke dalam tulisan sesuai dengan semua aktivitas guru dan peserta didik dalam proses pembelajaran. Hal ini meningkatkan kapasitas guru untuk menganalisis transkrip dan ada bukti nyata dari proses pembelajaran yang mungkin terlewatkan. Menurut Mutiani, Warmansyah, Syaharuddin \& Susanto (2020) menyatakan bahwa TBLA diyakini mampu membuka permasalahan yang terjadi pada saat pembelajaran sehingga guru mendapatkan masukan secara mendalam berdasarkan dialog yang terjadi.

Tujuan dalam penelitian ini adalah untuk mengidentifikasi pola dialog pembelajaran yang terbentuk pada materi fluida statis melalui Transcript Based Lesson Analysis (TBLA).

\section{METODOLOGI}

Harap dicatat bahwa Penulis harus mengikuti Urutan penulisan isi berikut ini: 1) Pendahuluan, 2) Metodologi / Isu / Fokus Penelitian / dll, 3) Hasil dan Pembahasan, dan 4) Kesimpulan. Penulis dapat menggunakan format atau nomenklatur lain selain yang disebutkan diatas, asalkan nyaman dan cocok dengan penelitian yang penulis lakukan dan tentunya mudah dipahami oleh pembaca artikel Anda. Namun yang harus penulis perhatikan adalah poin 1), 3) dan 4) harus tetap ada dengan nomenklatur yang dapat menyesuaikan dengan pilihan anda.

Metode penelitian merupakan cara ilmiah untuk mendapatkan data yang valid dengan tujuan dapat membuktikan suatu pengetahuan tertentu untuk memecahkan masalah dalam bidang pendidikan (Sugiyono, 2017). Dalam penelitian ini menggunakan metode kualitatif. Metode kualitatif merupakan metode yang digunakan untuk meneliti pada tempat yang alamiah, dan penelitian tidak membuat perlakuan, karena peneliti dalam mengumpulkan data bersifat emic, yaitu berdasarkan pandangan dari sumber data, bukan pandangan peneliti (Sugiyono, 2017). Bentuk penelitian yang digunakan dalam penelitian ini menggunakan bentuk penelitian deskriptif. Penelitian deskriptif adalah penelitian tentang isu-isu berupa fakta dari suatu populasi yang meliputi penilaian sikap atau pendapat terhadap individu, keadaan, ataupun prosedur (Sudaryono, 2017). Adapun populasi dalam penelitian ini adalah peserta didik kelas XI yang mempelajari tentang fluida statis yaitu kelas XI IPA 5 dan XI IPA 6 di SMA Negeri 3 Pontianak Tahun ajaran 2020/2021. Untuk 
pemilihan sampel dalam penelitian ini menggunakan teknik purposive sampling, sehingga diperoleh satu kelas XI PA 5 yang berjumlah 38 orang. Purposive sampling itu sendiri adalah teknik pengambilan sampel data yang didasarkan pada pertimbangan tertentu (Sugiyono, 2017).

Teknik pengumpulan data dalam penelitian ini mengarah pada tahapan kegiatan lesson study yaitu plan, do, dan see. Teknik pengumpulan data berupa dokumentasi dan observasi. Alat pengumpul data dalam penelitian ini berupa rekaman audio, rekaman video dan catatan lapangan. Data yang dikumpulkan berupa rekaman audio dan video selama pembelajaran berlangsung seperti yang tersaji pada Tabel 1.

Tabel 1 : Teknik Pengumpulan Data

\begin{tabular}{|c|c|c|c|}
\hline $\begin{array}{c}\text { Teknik } \\
\text { Pengumpulan } \\
\text { Data }\end{array}$ & $\begin{array}{c}\text { Tahapan } \\
\text { Lesson } \\
\text { Study }\end{array}$ & Data & Instrumen \\
\hline \multirow{3}{*}{ Dokumentasi } & Desain & $\begin{array}{l}\text { - Rekaman video } \\
\text { - Rekaman audio }\end{array}$ & $\begin{array}{l}\text { - Audio } \\
\text { recorder } \\
\text { - Video } \\
\text { recorder }\end{array}$ \\
\hline & Observasi & $\begin{array}{l}\text { - Rekaman audio } \\
\text { keseluruhan } \\
\text { pembelajaran } \\
\text { - Rekaman video } \\
\text { keseluruhan } \\
\text { pembelajaran } \\
\text { - Rekaman audio } \\
\text { peserta didik } \\
\text { (dalam } \\
\text { kelompok) } \\
\text { - Rekaman video } \\
\text { peserta didik } \\
\text { (dalam } \\
\text { kelompok) } \\
\text { - Transkrip } \\
\end{array}$ & $\begin{array}{l}\text { - Audio } \\
\text { recorder } \\
\text { - Video } \\
\text { recorder }\end{array}$ \\
\hline & Refleksi & Rekaman video & $\begin{array}{l}\text { Video } \\
\text { Recorder }\end{array}$ \\
\hline Observasi & - & $\begin{array}{l}\text { Catatan } \\
\text { lapangan }\end{array}$ & $\begin{array}{l}\text { Lembar } \\
\text { Catatan } \\
\text { Lapangan }\end{array}$ \\
\hline
\end{tabular}

Adapun prosedur penelitian yang digunakan dalam penelitian ini yaitu : 1) Tahap persiapan, mencari dan membaca kajian literatur yang terkait dengan judul penelitian, mempersiapkan audio rekaman dan video rekaman, mempersiapkan instrumen penelitian berupa lembar catatan lapangan untuk peserta didik. 2) Tahap pelaksanaan, observasi pembelajaran dilaksanakan. Pada saat observasi terdapat observer lain yang mengamati proses pembelajaran. 3) Tahap akhir, peneliti memperoleh pola dialog yang terjadi selama pembelajaran fisika di kelas untuk setiap siklus dengan karakteristiknya masingmasing. Seperti yang tersaji pada Gambar 1.

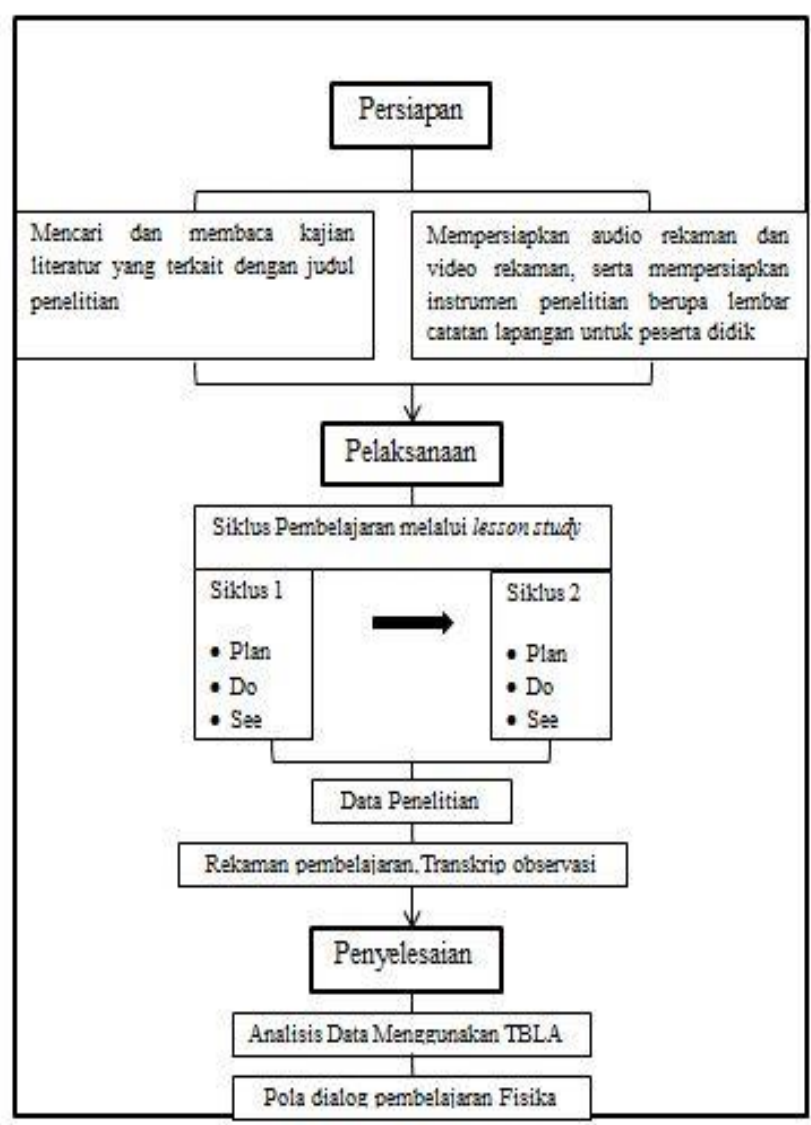

Gambar 1 : Prosedur Penelitian

Untuk menganalisis data dalam penelitian ini yaitu mentranskrip pembelajaran ke dalam bentuk verbal (full transcript). Transkrip ini didapatkan dari hasil dokumentasi berupa rekaman audio, video dan instan transcript selama dua siklus pembelajaran pada tahapan observasi yang merupakan data utama penelitian. Adapun tampilan transkrip yang diperoleh terdapat pada Tabel 2.

Tabel 2: Transkrip Pembelajaran

\begin{tabular}{|l|l|l|}
\hline Waktu & Pembicara & Ucapan \\
\hline $\begin{array}{l}\text { Jam : Menit } \\
\text { : Detik }\end{array}$ & $\mathrm{G}=$ guru & Ucapan \\
$\mathrm{S}=$ siswa & $\begin{array}{l}\text { dalam } \\
\text { pembelajaran }\end{array}$ \\
\hline
\end{tabular}




\begin{tabular}{|l|l|l|}
\hline & $\mathrm{G}_{1}$ & \\
\hline & $\mathrm{S}_{1}$ & \\
\hline & $\mathrm{G}_{2}$ & \\
\hline & $\mathrm{S}_{2}$ & \\
\hline
\end{tabular}

Sumber : (Rahayu, 2019)

Dari hasil transkrip yang diperoleh tersebut kemudian dianalisis pola dialog pembelajarannya. Kemudian untuk memperkuat analisis hasil transkrip tersebut dapat dikuantisasi dengan melakukan analisis di excell yang kemudian ditabulasikan. Adapun tabulasi ucapan guru dan peserta didik dapat disajikan pada Tabel 3.

Tabel 3 : Tabulasi Ucapan Guru dan Peserta Didik

\begin{tabular}{|c|c|c|c|c|c|c|c|c|}
\hline & \multicolumn{8}{|c|}{ Urutan Waktu } \\
\hline \multirow{2}{*}{$\begin{array}{l}\text { No. } \\
1 .\end{array}$} & \multicolumn{2}{|c|}{$\begin{array}{l}\text { Menit } \\
\text { ke- }\end{array}$} & \multicolumn{2}{|c|}{$\begin{array}{l}\text { Menit } \\
\text { ke- }\end{array}$} & \multicolumn{2}{|c|}{$\begin{array}{c}\text { Menit } \\
\text { ke- }\end{array}$} & \multicolumn{2}{|c|}{$\begin{array}{c}\text { Menit } \\
\text { ke- }\end{array}$} \\
\hline & $\begin{array}{l}\% \\
\mathrm{U} . \\
\mathrm{G}\end{array}$ & $\begin{array}{c}\% \\
\mathrm{U} . \\
\mathrm{S}\end{array}$ & $\begin{array}{l}\% \\
\mathrm{U} . \\
\mathrm{G}\end{array}$ & $\begin{array}{l}\% \\
\mathrm{U} . \\
\mathrm{S}\end{array}$ & $\begin{array}{l}\% \\
\mathrm{U} . \\
\mathrm{G}\end{array}$ & $\begin{array}{c}\% \\
\mathrm{U} . \\
\mathrm{S}\end{array}$ & $\begin{array}{l}\% \\
\mathrm{U} . \\
\mathrm{G}\end{array}$ & $\begin{array}{c}\% \\
\mathrm{U} . \\
\mathrm{S}\end{array}$ \\
\hline & & & & & & & & \\
\hline$\sum_{U . G}$ & & & & & & & & \\
\hline $\begin{array}{c}\text { Rata } \\
- \\
\text { Rata } \\
\text { U.G }\end{array}$ & & & & & & & & \\
\hline$\sum_{\text {U.S }}$ & & & & & & & & \\
\hline $\begin{array}{c}\text { Rata } \\
- \\
\text { Rata } \\
\text { U.S }\end{array}$ & & & & & & & & \\
\hline
\end{tabular}

Keterangan :

\% U.G : Persentase Ucapan Guru

$\%$ U.S : Persentase Ucapan Siswa

$\sum$ U.G : Jumlah Ucapan Guru

$\sum$ U.S : Jumlah Ucapan Siswa

Setelah semua data dimasukkan ke dalam tabel tabulasi, kemudian direkap seperti yang ditunjukkan pada Tabel 4 .

Tabel 4 : Rekapitulasi Ucapan Guru dan Peserta Didik

\begin{tabular}{|l|l|l|l|}
\hline$\sum$ U.G & Rata- & $\sum$ U.S & Rata- \\
\hline
\end{tabular}

\begin{tabular}{|l|l|l|l|}
\hline & $\begin{array}{l}\text { Rata } \\
\text { U.G }\end{array}$ & & Rata U.S \\
\hline
\end{tabular}

Keterangan :

$\sum$ U.G : Jumlah Ucapan Guru

$\sum$ U.S : Jumlah Ucapan Siswa

\section{HASIL DAN PEMBAHASAN}

\section{Hasil Penelitian}

Berdasarkan hasil penelitian, data diperoleh dari hasil perekaman audio dan video selama pembelajaran berlangsung yang kemudian dibuat transkrip ke dalam bentuk verbal. Selanjutnya dari data transkrip tersebut dianalisis pola dialognya. Macam-macam pola dialog dalam pembelajaran ada 5 yang dikemukakan oleh Usman (2014) yaitu : pola komunikasi satu arah, pola komunikasi dua arah, pola komunikasi tiga arah, pola komunikasi multi arah, dan pola komunikasi segala arah. Untuk siklus 1 dilaksanakan pada tanggal 2 November 2020 yang secara ringkas hasil transkrip pembelajarannya dapat dilihat pada Gambar 2.

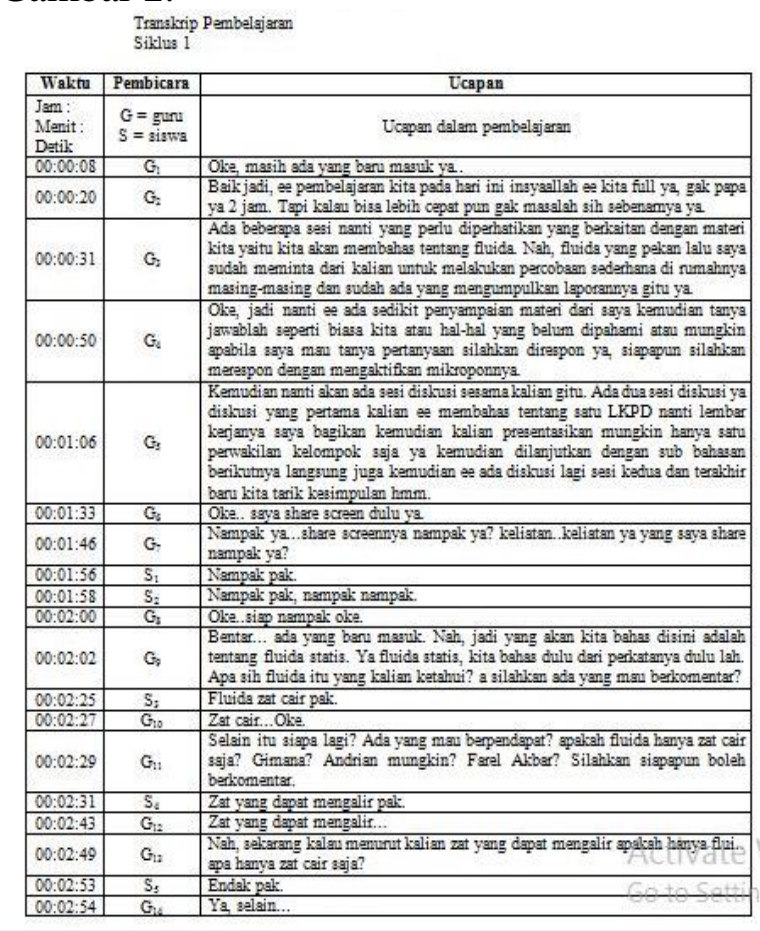

Gambar 2: Transkrip pembelajaran siklus 1

Berdasarkan Gambar 2 secara keseluruhan pembelajaran tersebut dianalisis 
untuk mendapatkan pola dialog pembelajaran yang terbentuk. Hasil analisis dalam kegiatan pembelajaran sudah terlihat pada awal pembelajaran dimana ketika guru mengajukan pertanyaan kepada peserta didik tentang pengetahuan awal mereka pada materi fluida, peserta didik antusias menjawab seperti yang terlihat pada cuplikan percakapan di bawah ini yaitu :

G9 : Bentar... ada yang baru masuk. Nah, jadi yang akan kita bahas disini adalah tentang fluida statis. Ya fluida statis, kita bahas dulu dari prakatanya dulu lah. Apa sih fluida itu yang kalian ketahui? aa silahkan ada yang mau berkomentar?.

$\mathrm{S}_{3} \quad$ : Fluida zat cair pak.

$\mathrm{G}_{10}$ : Zat cair...oke.

$\mathrm{G}_{11}$ : Selain itu siapa lagi? Ada yang mau berpendapat? Apakah fluida hanya zat cair saja? Gimana? Andrian mungkin? Farel Akbar? Silahkan siapapun boleh berkomentar.

$\mathrm{S}_{4} \quad$ : Zat yang dapat mengalir pak.

$\mathrm{G}_{12}$ : Zat yang dapat mengalir...

$\mathrm{G}_{13}$ : Nah, sekarang kalau menurut kalian zat yang dapat mengalir apakah hanya fluida...apa hanya zat cair saja?

$\mathrm{S}_{5} \quad$ : Endak pak.

$\mathrm{G}_{14}$ : Ya, selain...

$\mathrm{S}_{6} \quad$ : Udara juga.

Berdasarkan cuplikan di atas terlihat bahwa guru berperan aktif dalam mengelola pembelajaran yaitu dengan terus mengajukan pertanyaan untuk menggali pengetahuan peserta didik. Sehingga dalam pembelajaran tersebut peserta didik juga aktif dengan memberikan pendapatnya. Hal ini berarti adanya timbal balik antara guru dan peserta didik. Kemudian pada waktu 01:27:34 ada peserta didik yang bertanya seperti pada cuplikan transkrip di bawah ini yaitu :

$\mathrm{G}_{208}$ : Ada tanggapan mungkin dari kelompok yang lain, karena mungkin ada perbedaan hasil atau kesimpulan. Ada gak dari kelompok 1 mungkin, kelompok 2, sampai kelompok 6?.

$\mathrm{S}_{134}$ : Saya pak, rizky pardosi dari kelompok 6.
$\mathrm{G}_{209}$ : Aa oke...silahkan rizky gimana tanggapannya.

$\mathrm{S}_{135}$ : Saya mau nanyak pak, yang tadik dibilang infus kenape bise masuk kedalam hidrostatis? Terimakasih pak itu aja.

$\mathrm{G}_{210}$ : Oke silahkan ee dari kelompok Yusuf Anas bisa menjelaskan kenapa infus masuk ke dalam tekanan hidrostatis? Alasannya apa?.

$\mathrm{S}_{136}$ : Andry pak yang jawab.

Berdasarkan hasil analisis pada cuplikan percakapan antara guru dan peserta didik secara klasikal diperoleh bahwa guru dan peserta didik sama-sama aktif dan terjadi hubungan timbal balik. Dimana ketika guru memberikan pertanyaan kepada peserta didik, lalu peserta didik langsung menjawab pertanyaan guru begitupun sebaliknya ketika peserta didik mengajukan pertanyaan guru pun langsung menanggapi. Hal ini dapat dikatakan bahwa pola dialog pembelajaran yang terbentuk pada siklus 1 adalah pola komunikasi dua arah. Selain itu, untuk menganalisis pola dialognya juga didukung dengan beberapa data hasil persentase jumlah kata yang diucapkan guru dan peserta didik seperti yang ditunjukkan pada Tabel 5.

Tabel 5 : Rekapitulasi Ucapan Guru dan Peserta Didik Siklus 1

\begin{tabular}{|c|c|c|c|}
\hline$\sum$ U.G & $\begin{array}{c}\text { Rata- } \\
\text { Rata } \\
\text { U.G }\end{array}$ & $\sum$ U.S & $\begin{array}{c}\text { Rata- } \\
\text { Rata U.S }\end{array}$ \\
\hline $100,12 \%$ & $7,70 \%$ & $99,99 \%$ & $7,70 \%$ \\
\hline
\end{tabular}

Keterangan :

$\sum$ U.G : Jumlah Ucapan Guru

$\sum$ U.S : Jumlah Ucapan Siswa

Berdasarkan Tabel 5, diperoleh bahwa rata-rata jumlah kata yang diucapkan guru sebesar $7,70 \%$ dan rata-rata jumlah kata yang diucapkan peserta didik sebesar 7,70\%. Ini menunjukkan bahwa adanya keseimbangan antara guru dan peserta didik. Hal ini berarti antara guru dan peserta didik sama-sama aktif dan terjadi hubungan timbal balik. 
Kemudian untuk siklus 2 dilaksanakan pada tanggal 9 November 2020 yang secara ringkas hasil transkrip pembelajarannya dapat dilihat pada Gambar 3.

\begin{tabular}{|c|c|c|}
\hline Waktu & Permbicars & Ucapen \\
\hline $\begin{array}{l}\text { Jam: } \\
\text { Menit: } \\
\text { Detil: }\end{array}$ & $\begin{array}{l}\text { G } \\
\text { S }\end{array}$ & Ucspan dalam pembelajaran \\
\hline $00: 00: 02$ & $G_{1}$ & 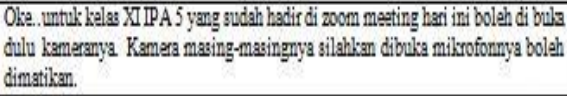 \\
\hline 00:00:19 & G: & $\begin{array}{l}\text { Oke, baik hmm oles sudah } 26 \text { orang dan sudah a lewat weltu toleranai ya sudah } 5 \\
\text { menit kita bulka saja. }\end{array}$ \\
\hline $00: 00: 52$ & G; & 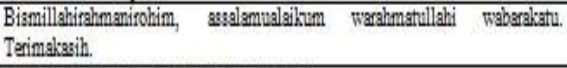 \\
\hline $00: 00: 57$ & $S_{1}$ & Wralgihumsalem wrahmatullahi wabraksatu \\
\hline $00: 00: 59$ & $S_{2}$ & Wraldihumselam \\
\hline $00: 01: 01$ & $\mathrm{G}_{8}$ & $Y_{s}$ \\
\hline $00: 01: 03$ & $\mathrm{~S}_{i}$ & Wralaikumalam wrahmahullah \\
\hline $00: 01: 04$ & $G_{3}$ & Alhondulillah. mudah-mudahan yang jarrob salomnye depat pehale ye. \\
\hline $00: 01: 08$ & $G_{6}$ & 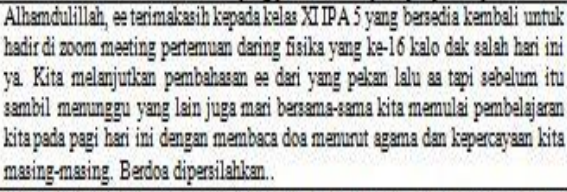 \\
\hline $00: 01: 47$ & G. & 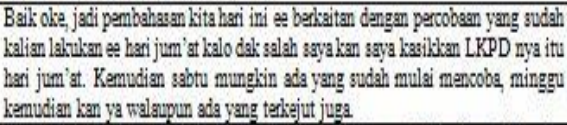 \\
\hline $00: 02: 09$ & $G_{1}$ & 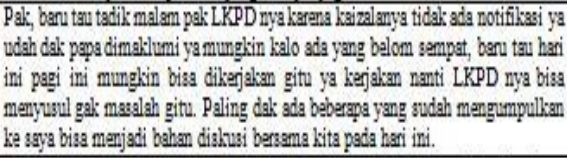 \\
\hline $00: 02: 33$ & $G_{8}$ & 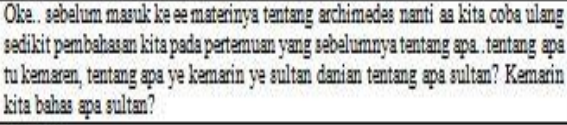 \\
\hline $00: 02: 56$ & $S_{4}$ & Ape pak: \\
\hline $00: 02: 58$ & $\mathrm{G}_{i 0}$ & Kemsrin kita bahas gpa ya hari senin tu ye? \\
\hline $00: 03: 01$ & S: & Kurang tau juga pak \\
\hline $00: 03: 03$ & $\mathrm{G}_{11}$ & Oh heha tapi ada ngilutin kem arin kan ya ads masulk zoom mesting gak kem arin? \\
\hline $00: 03: 07$ & $S_{6}$ & Tadsk pak, kemarin habis luots \\
\hline $00: 03: 08$ & $\mathrm{G}_{i:}$ & Ohh. habis knota obh ivg lah. \\
\hline 00:03:11 & $G_{i j}$ & Gase innocen? Gimana grace kemarin bahas spa kita grace? \\
\hline $00: 03: 20$ & S, & Teleanan hidrostatis \\
\hline
\end{tabular}

Gambar 3: Transkrip pembelajaran siklus 2

Berdasarkan Gambar 3 secara keseluruhan pembelajaran tersebut dianalisis untuk mendapatkan pola dialog pembelajaran yang terbentuk. Hasil analisis dalam kegiatan pembelajaran terlihat pada saat guru menampilkan dua buah gambar yang berbeda dan meminta peserta didik untuk memperhatikan gambar tersebut. Kemudian guru mengajukan pertanyaan kepada peserta didik, lalu mereka antusias menjawab seperti yang terlihat pada cuplikan percakapan di bawah ini yaitu :
$\mathrm{G}_{23}$ : Berdasarkan kedua gambar tersebut apa yang dapat kalian amati dan mengapa hal tersebut bisa terjadi? Coba ada yang mau berpendapat silahkan coba suaranya dibuka mikrofonnya...ada yang mau berpendapat?.

$\mathrm{S}_{12} \quad$ : Pak.

$\mathrm{G}_{24}$ : Ya silahkan.

$\mathrm{S}_{13}$ : Ee kalo menurut saya yang batu itu yang di dalam aquarium dia tenggelam karena batu atau bola pejal itu tu di dalamnye tu tidak terdapat rongga udara, sehingga membuat benda itu menjadi tenggelam. Ee apabila benta itu diisi rongga berarti benda itu massa jenisnya akan lebih kecil sehingga membuat benda itu menjadi mengapung. Sebaliknya jika dia penuh seperti bentuk bakso maka benda tersebut akan tenggelam.

$\mathrm{G}_{25}$ : Oke...Syarifah Zulfa, terimakasih untuk pendapatnya ada yang beda pendapat mungkin dari zulfa. Tadik kan kalo zulfa melihat dari yang batunya ya batu yang tenggelam.

$\mathrm{G}_{26}$ : Nah, kalo yang soal kapal gimana coba asa yang mau berpendapat tadik zulfa sudah bagus. Bedanya dengan batu apa perasaankan sama-sama zat padatlah ya kapal kan zat padat batu juga zat padat. Kok bisa batunya masuk dalam air tapi kapalnya ee diatas permukaan gitu.

$\mathrm{S}_{16} \quad$ : Pak..pak.

$\mathrm{G}_{27}$ : Tengku...aa siapa? Suara siapa tadik tu andryan mungkin?

$\mathrm{S}_{17}$ : Iya pak.

$\mathrm{G}_{28}$ : Andryan mau jawab silahkan.

$\mathrm{S}_{18}$ : Karena kapal tu memiliki luas permukaan yang besar kalo batu luas permukaannya kecil.

Berdasarkan cuplikan di atas terlihat bahwa guru berperan aktif dalam mengelola pembelajaran yaitu dengan terus meminta peserta didik menyampaikan pendapatnya. Dengan demikian peserta didik menjadi aktif dan tanpa ditunjuk pun mereka dengan sendirinya langsung mengemukakan 
pendapatnya. Hal ini berarti adanya timbal balik antara guru dan peserta didik. Selain itu, hal itu juga didukung dengan beberapa data hasil persentase jumlah kata yang diucapkan oleh guru dan peserta didik seperti yang ditunjukkan pada Tabel 6 .

Tabel 6 : Rekapitulasi Ucapan Guru dan Peserta Didik Siklus 2

\begin{tabular}{|c|c|c|c|}
\hline$\sum$ U.G & $\begin{array}{c}\text { Rata- } \\
\text { Rata } \\
\text { U.G }\end{array}$ & $\sum$ U.S & $\begin{array}{c}\text { Rata- } \\
\text { Rata U.S }\end{array}$ \\
\hline $100,04 \%$ & $8,34 \%$ & $99,99 \%$ & $8,33 \%$ \\
\hline
\end{tabular}

Keterangan :

$\sum$ U.G : Jumlah Ucapan Guru

$\sum$ U.S : Jumlah Ucapan Peserta Didik

Berdasarkan Tabel 6, diperoleh bahwa rata-rata jumlah kata yang diucapkan guru sebesar $8,34 \%$ dan rata-rata jumlah kata yang diucapkan peserta didik sebesar $8,33 \%$. Ini menunjukkan bahwa adanya keseimbangan antara guru dan peserta didik. Hal ini berarti antara guru dan peserta didik sama-sama aktif dan terjadi hubungan timbal balik.

Kemudian pada menit ke-20 saat guru memberikan pertanyaan kepada peserta didik, peserta didik langsung menjawab dan saling berdebat dengan jawaban mereka masing-masing seperti yang termuat pada cuplikan percakapan di bawah ini yaitu :

$\mathrm{G}_{85}$ : Lebih ringan gimana dulu ni kalo saya tanya lebih ringan jalan di udara atau jalan di dalam air?.

$\mathrm{S}_{39}$ : Udara sih pak.

$\mathrm{S}_{40}$ : Udara.

$\mathrm{G}_{86}$ : Jadi lebih berat di udara apa di air?.

$\mathrm{S}_{41}$ : Air.

$\mathrm{S}_{42}$ : Di air.

$\mathrm{G}_{87}$ : Hehe.

$\mathrm{S}_{43}$ : Di udara lah lebih berat.

$\mathrm{S}_{44} \quad$ : Di air lah lebih berat.

$\mathrm{G}_{88} \quad$ : Di air apa di udara?.

$\mathrm{S}_{45}$ : Air lebih berat di air.

$\mathrm{G}_{89}$ : Lebih berat di air ya tergantung sebenarnya jawabannya tergantung, kalo saya tanya geraknya secara horizontal...horizontal tu berarti berjalan maksudnya ya ya jelas dong lebih ringan berjalan di udara ya kan dibandingkan berjalan ee di air.

Berdasarkan cuplikan di atas terlihat bahwa peserta didik saling berargumen dan guru yang menengahkan dengan memberikan jawaban yang benar. Hal ini berarti adanya timbal balik antara guru dan peserta didik, serta antar peserta didik juga terjadi interaksi. Selain itu, hal ini juga didukung oleh beberapa data hasil persentase jumlah kata yang diucapkan oleh guru dan peserta didik seperti yang ditunjukkan pada Tabel 7.

Tabel 7 : Persentase Ucapan Guru dan Peserta Didik pada Menit ke-20

\begin{tabular}{|c|c|}
\hline$\%$ U.G & $\%$ U.S \\
\hline $1,13 \%$ & $1,74 \%$ \\
\hline
\end{tabular}

Keterangan :

\% U.G : Persentase Ucapan Guru

$\%$ U.S : Persentase Ucapan Siswa

Berdasarkan Tabel 7, diperoleh bahwa persentase yang diucapkan oleh guru sebesar $1,13 \%$ dan persentase yang diucapkan peserta didik sebesar $1,74 \%$. Ini menunjukkan adanya hubungan timbal balik antara guru dan peserta didik, namun peserta didik cenderung lebih aktif. Hal ini karena, peserta didik saling berargumen antara satu dengan yang lain. Sehingga peserta didik lebih banyak berbicara dibandingkan guru.

Berdasarkan hasil analisis pada cuplikan percakapan antara guru dan peserta didik secara klasikal diperoleh bahwa guru dan peserta didik sama-sama aktif dimana terjadi hubungan timbal balik. Hal ini berarti pola dialog yang terbentuk yaitu pola komunikasi dua arah. Kemudian pada menit ke-20 itu terdapat pola komunikasi tiga arah yang mana antara guru dan peserta didik terjadi hubungan timbal balik dan antar peserta didik juga terjadi interaksi. Jadi, dapat dikatakan bahwa pada siklus 1 dan siklus 2 pola dialog pembelajaran yang terbentuk di kelas XI IPA 5 sama-sama menggunakan pola komunikasi dua arah. Namun, pada siklus 2 juga terdapat pola komunikasi tiga 
arah. Dan yang membedakan antara siklus 1 dan siklus 2 adalah pembelajaran yang terjadi pada siklus 2. Dimana peserta didik cenderung lebih aktif dibandingkan siklus 1 . Hal ini berarti pada siklus 2 mengalami peningkatan dalam pembelajaran.

\section{PEMBAHASAN}

Berdasarkan hasil penelitian yang telah dilakukan pada siklus 1 diperoleh sebuah pola dalam pembelajaran. Pola pembelajaran ini dianalisis berdasarkan Transcript Based Lesson Analysis (TBLA). Karena dengan TBLA diyakini mampu membuka permasalahan yang terjadi pada saat pembelajaran sehingga guru mendapatkan masukan secara mendalam berdasarkan dialog yang terjadi (Mutiani, Warmansyah, Syaharuddin \& Susanto, 2020). Pola dialog pembelajaran yang terbentuk di dalam kelas adalah pola komunikasi dua arah. Hal ini sesuai dengan pendapat yang dikemukakan oleh Usman (dalam Djamarah, 2014) yang menyatakan bahwa ada balikan bagi guru, tidak ada interaksi antar peserta didik (komunikasi sebagai interaksi) seperti yang terlihat pada Gambar 4.

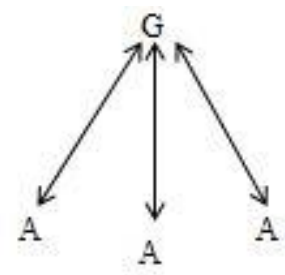

Sumber : (Usman dalam Djamarah, 2014)

Gambar 4: Pola komunikasi dua arah

Berdasarkan paparan pendapat di atas dapat disimpulkan bahwa guru dan peserta didik terjadi hubungan timbal balik, sedangkan antara peserta didik dengan peserta didik tidak ada interaksi. Hal ini dapat dibuktikan pada cuplikan transkrip pembelajaran di atas. Dari cuplikan tersebut dapat dilihat bahwa guru dan peserta didik sama-sama aktif. Dimana ketika guru memberikan pertanyaan kepada peserta didik kemudian peserta didik merespon atas pertanyaan yang disampaikan oleh guru. Hal ini berarti adanya hubungan timbal balik antara guru dan peserta didik. Yang mana juga didukung dengan data hasil persentase jumlah kata yang diucapkan guru dan peserta didik. Untuk persentase rata-rata jumlah kata yang diucapkan oleh guru sebesar $7,70 \%$ dan peserta didik sebesar $7,70 \%$. Dari hasil data ini terlihat bahwa adanya keseimbangan antara guru dan peserta didik. Hal ini berarti adanya hubungan timbal balik antara guru dan peserta didik. Peran guru sangat penting dalam penguasaan kondisi kelas. Ketika guru dapat membuat peserta didik menjadi aktif di dalam kelas berarti guru sudah berhasil menghidupkan suasana kelas dan membuat peserta didik bersemangat dalam mengikuti pembelajaran.

Kemudian, pada siklus 1 ini sebelum masuk pada pembelajaran peserta didik diberikan lembar kerja peserta didik (LKPD) tentang tekanan hidrostatis yang akan dikerjakan secara individu di rumahnya masing-masing. Berhubung sekarang masih masa pandemi (Covid 19) dan berbagai pertimbangan dari guru yang mengajar maka tidak memungkinkan peserta didik untuk bekerja secara berkelompok.

Kemudian LKPD yang telah mereka kerjakan dan isi datanya dikumpulkan kepada guru sebelum masuk pada hari dimana pembelajaran berlangsung. Tujuan diberikannya LKPD di awal yaitu agar peserta didik belajar secara mandiri dulu di rumah sehingga pada saat masuk ke pembelajaran dapat mengikuti dengan baik dan ternyata benar peserta didik aktif dalam pembelajaran.

Pada saat pembelajaran berlangsung itu dilakukan 2 kali sesi diskusi kelompok. Diskusi pertama yaitu membahas lanjutan dari LKPD yang diberikan di awal sebelum masuk pada pembelajaran. Di dalam diskusi tersebut terdapat 6 room dimana di dalam tiap roomnya terdapat observer yang mengamati peserta didik dan merekam audio serta video pada saat peserta didik diskusi. Untuk transkrip diskusi tiap roomnya dapat dilihat pada (Lampiran B-01) dimana peserta didik di setiap room terlihat aktif satu sama lain. 
Selanjutnya pada diskusi yang kedua yaitu membahas LKPD tentang hukum pascal. Di dalam diskusi tersebut juga terdapat 6 room yang terdapat observer yang mengamati jalannya diskusi. Untuk transkrip diskusi tiap roomnya juga dapat dilihat pada (Lampiran B-01) dimana peserta didik disetiap room terlihat aktif satu sama lain, namun ada 1 room yang tidak ada diskusi sama sekali yaitu pada room 6. Menurut observer yang mengamati di dalam room tersebut menyatakan memang tidak ada terjadi diskusi sama sekali.

Pada siklus 2 secara klasikal pola dialog pembelajaran yang terbentuk di dalam kelas juga pola komunikasi dua arah dimana guru dan peserta didik sama-sama aktif. Hal ini dibuktikan pada cuplikan transkrip pembelajaran di atas yang termuat di dalam (Lampiran B-02). Dari cuplikan tersebut dapat dilihat bahwa guru dan peserta didik sama-sama aktif. Dimana ketika guru memberikan pertanyaan kepada peserta didik kemudian peserta didik dengan antusias langsung merespon dan mengemukakan pendapatnya tanpa ditunjuk oleh guru. Hal ini juga didukung oleh data hasil persentase rata-rata jumlah kata yang diucapkan oleh guru dan peserta didik. Untuk persentase rata-rata yang diucapkan oleh guru sebesar 8,34\% dan peserta didik sebesar 8,33\%. Hal ini menunjukkan adanya keseimbangan antara guru dan peserta didik. Ini berarti antara guru dan peserta didik sama-sama aktif dan adanya hubungan timbal balik antara guru dan peserta didik.

Selain itu, pada siklus 2 ini juga terdapat pola komunikasi tiga arah yaitu pada menit ke-20 dengan cuplikan transkrip pembelajaran di atas yang termuat di dalam (Lampiran B-02). Dimana ketika guru memberikan pertanyaan, peserta didik langsung menjawab dan masing-masing peserta didik berdebat memberikan argumennya masing-masing. Kemudian guru menengahkan dengan memberikan jawaban yang benar. Hal ini juga didukung dari data hasil persentase ucapan guru dan peserta didik. Dimana persentase ucapan guru sebesar $1,13 \%$ dan persentase ucapan peserta didik sebesar 1,74\%. Ini berarti adanya hubungan timbal balik antara guru dan peserta didik, namun peserta didik cenderung lebih aktif. Hal ini karena peserta didik saling berdebat antara satu dan lainnya, sehingga peserta didik lebih banyak berbicara dibandingkan guru. Hal ini sesuai dengan pendapat yang dikemukakan oleh Usman (dalam Djamarah 2014) yang menyatakan bahwa ada balikan bagi guru, anak didik saling belajar satu sama lain. Seperti yang ditunjukkan pada Gambar 5.

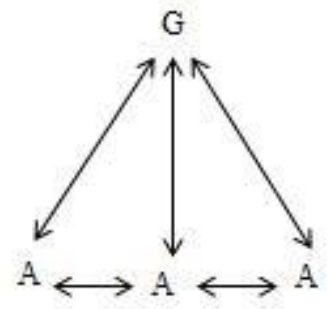

Sumber : (Usman dalam Djamarah, 2014)

Gambar 5: Pola Komunikasi Tiga Arah

Kemudian jika dilihat dari keseluruhan pembelajaran siklus 2 mengalami peningkatan dalam pembelajaran dimana peserta didik sudah banyak yang mulai berani mengajukan pertanyaan seperti pada cuplikan transkrip sebagai berikut :

Pada menit ke-17...

$\mathrm{G}_{75}$ : Paham dak maksudnya ni atau bingung hmm bingung?

$\mathrm{S}_{33}$ : Fluida yang dipindahkan tu maksudnye ape pak? Yang tumpah ke?.

$\mathrm{G}_{76}$ : Fluida yang dipindahkan tu iya fluida yang dipindahkan adalah fluida yang tumpah betol.

Pada menit ke-33...

$\mathrm{G}_{142}$ : Ada lagi?.

$\mathrm{S}_{77} \quad$ : Saya pak.

$\mathrm{G}_{143}$ : Gimana?.

$\mathrm{S}_{78} \quad$ : Saya maok nanyak.

$\mathrm{G}_{144}$ : Aa nanyak apa silahkan.

$\mathrm{S}_{79}$ : Yang balon udara tu ngape bise masok fluida?.

$\mathrm{G}_{145}$ : Kalo balon..balon udara itu yang menjadi fluidanya adalah ya udara di sekitar balo udaranya itu ya kan, makanya kemaren fluida kan ada 2 jenis zat ada zat cair ada udara atau 
gas ya kan. Nah, jadi kalo dalam balon udara fluidanya adalah zat gasnya.

Pada waktu 01:30:03...

$\mathrm{G}_{257}$ : Jangan buru-buru mungkin habis ini mau istirahat atau ape.

$\mathrm{S}_{182}$ : Pak maok nanyak.

$\mathrm{G}_{258}$ : Oh silahkan maok nanyak silahkan...

$\mathrm{S}_{183}$ : Benda yang dipindahkan tu dapat darimane? Kelompok kamek tak ngerti dari tadik soalnye tu tadik tu salah link pakek link yang lama..

$\mathrm{G}_{259}$ : Oh kelompok mana ni salah link ni?.

$\mathrm{S}_{184}: 4$.

Kemudian peserta didik sudah ada yang berani menyanggah seperti pada cuplikan transkrip sebagai berikut :

Pada waktu 01:22:18...

$\mathrm{G}_{201}$ : Yang lain ada pertanyaan? Ada yang hasil gaya apungnya sama dengan berat airnya atau sama kayak kelompok fajar sampai berjuta-juta hmm?.

$\mathrm{S}_{123}$ : Ee same pak.

$\mathrm{S}_{124}$ : Same pak.

$\mathrm{G}_{202}$ : Sama kayak kelompok fajar berarti ya?.

$\mathrm{S}_{125}$ : Dak pak, dak bejuta-juta.

$\mathrm{G}_{203}$ : Ya nanti diperbaiki ya yang keliru ya jadi...

$\mathrm{S}_{126} \quad$ : Dak dak bede pak bede.

$\mathrm{S}_{127}$ : Dak pak dak pak.

$\mathrm{G}_{204}$ : Oh bede hehe, yang mane yang bede?.

$\mathrm{S}_{128}$ : Dak.

$\mathrm{G}_{205}$ : Kelompok siapa ni yang bede? Hehe.

$\mathrm{S}_{129}$ : Bede pak.

$\mathrm{G}_{206}$ : Kalian sa.. gimana kelompoknya rizki ka ini?.

$\mathrm{S}_{130}$ : Kamek sih 20 ribuan pak, 520 ribuan.

$\mathrm{S}_{131} \quad$ : Saye.. saye dak sampe bejuta-juta pak.

$\mathrm{G}_{207}$ : Aa boleh boleh share screen mungkin yang kelompoknya siapa ini.
Serta pada saat presentasi kelompok tanpa ditunjuk peserta didik langsung menawarkan diri untuk presentasi. Seperti pada cuplikan transkrip sebagai berikut :

Pada waktu 01:16:11...

$\mathrm{S}_{83}$ : Pak, kembali diskusi ka atau langsung jak?.

$\mathrm{G}_{158}$ : Langsung aja oke langsung aja kita bahas 1 atau 2 kelompok lah.

$\mathrm{S}_{84} \quad$ : Kelompok saya jak pak.

$\mathrm{G}_{159}$ : Nanti..oke silahkan nanti yang belom selesai bisa diselesaikan setelah zoom meeting ini gitu bisa dirapikan.

Hal ini sejalan dengan penelitian yang dilakukan oleh Pratiwi, dkk (2016) yang menyatakan bahwa keaktifan belajar peserta didik dalam kategori aktif dan sangat aktif terjadi pada siklus II. Selain itu, hal ini juga sejalan dengan penelitian yang dilakukan oleh Mutiani, Warmansyah, Syaharuddin, \& Susanto (2020) yang menyatakan bahwa peningkatan dilihat dari siklus kedua dan peningkatan nampak dari kualitas percakapan yang terjadi antara guru dan peserta didik.

Kemudian sebelum masuk pada pembelajaran peserta didik juga diberikan LKPD tentang hukum archimedes yang akan dikerjakan secara individu di rumahnya masing-masing. Kemudian LKPD yang telah mereka kerjakan dan isi datanya dikumpulkan kepada guru sebelum masuk pada hari dimana pembelajaran berlangsung. Tujuan diberikannya LKPD di awal lagi yaitu berdasarkan pada apa yang terjadi pada siklus 1 dimana peserta didik menjadi aktif. Di dalam diskusi tersebut terdapat 6 room dimana di dalam tiap roomnya terdapat observer yang mengamati peserta didik dan merekam audio serta video pada saat peserta didik melakukan diskusi. Untuk transkrip diskusi tiap roomnya dapat dilihat pada (Lampiran B-02) dimana peserta didik di setiap room terlihat aktif satu sama lain.

Berdasarkan hasil yang telah dipaparkan kita dapat mengetahui pola dialog apa yang terbentuk di dalam pembelajaran tersebut. Hal ini dapat dijadikan sebagai referensi untuk guru agar lebih kreatif lagi dalam 
mengelola kelas dan dapat meningkatkan model pembelajaran yang lebih efektif. Karena interaksi antara guru dan peserta didik sangat penting dalam pembelajaran. Oleh karena itu diperlukan keterampilan guru dalam menghidupkan suasana kelas. Seperti pendapat yang dipaparkan oleh Sudjana \& Usman (dalam Djamarah, 2014) yang menyatakan bahwa perlu adanya keterampilan guru dalam mengelola kegiatan interaksi belajar mengajar.

Dalam penelitian ini kegiatan pembelajaran mengarah pada tahapan lesson study yaitu plan, do dan see. Karena dengan lesson study memberikan dampak yang positif yaitu : membantu guru mengkritisi pembelajarannya berdasarkan hasil reflektif, membantu guru dalam memantau aktivitas peserta didik secara lebih detail karena bantuan observer dan meningkatkan kolaborasi guru dalam team teaching (Amintarti, dkk, 2020). Kemudian pelaksanaan pembelajaran lebih terarah karena adanya masukan dan saran dari guru serta dosen pada saat merancang pembelajaran. Selain itu, lesson study tentu menjadi sumber inspirasi pembelajaran bersama terhadap kekurangan dan kelebihan yang dilakukan oleh semua anggota lesson study mulai dari plan (perencanaan), do (pelaksanaan), dan see (refleksi) (Sucilestari \& Arizona, 2019). Oleh karena itu, lesson study dapat meningkatkan kualitas pembelajaran.

Kemudian pada saat pembelajaran berlangsung juga dibantu oleh observer yang mengamati peserta didik baik dalam diskusi besar maupun diskusi kelompok. Setelah selesai pembelajaran para observer mengemukakan pendapatnya yang menyatakan bahwa pembelajaran pada siklus 2 lebih baik dari pada siklus 1 . Keberadaan observer di dalam kelas juga tidak membuat canggung peserta didik, mereka tetap melakukan diskusi sebagaimana mestinya. Setelah pembelajaran selesai dilakukanlah refleksi untuk memperbaiki pembelajaran berikutnya.
Format makalah ini disusun dengan tujuan agar dapat digunakan sebagai acuan untuk menulis abstrak sesuai dengan format yang dibutuhkan pada Seminar Nasional Penerapan Ilmu Pengetahuan dan Teknologi (PIPT) yang akan diselenggarakan oleh Universitas Tanjungpura di Gedung Konferensi Untan, Pontianak. Margin halaman mengikuti aturan berikut: $1,5 \mathrm{~cm}$ margin kiri dan kanan, $2.5 \mathrm{~cm}$ margin atas dan bawah. Gunakan font times new roman dengan baris satu spasi, dengan perataan kiri dan kanan (justified).

Judul makalah 12 point, semua kapital, centered, diikuti dengan satu baris kosong. Nama penulis diketik dengan ukuran 10 point, bold, centered. Antar nama penulis masing-masing dipisahkan dengan koma dan diikuti dengan angka (superscript) untuk membedakan institusinya. Institusi penulis diketik dengan 10 point, italic, centered diketik dalam baris yang terpisah antara institusi yang berbeda, dan diikuti dengan satu baris kosong. Email korespondensi diketik dengan 10 point, italic, centered diikuti dengan dua baris kosong. Makalah dikirimkan melalui OCS di pipt.untan.ac.id paling lambat pada tanggal yang tertera di pamflet. Isi makalah menjadi dasar penilaian dan penerimaan dari makalah yang akan dipresentasikan di seminar nanti.

Bagi yang makalahnya diterima untuk dipresentasikan, diharapkan untuk mentrasfer biaya kontribusi kepada panitia Seminar Nasional PIPT Untan, ke rekening BNI No. VA 8134201901170331 (a.n. Seminar Penerapan Ilmu Pengetahuan dan Teknologi) dan scan bukti transfer dikirim melalui OCS di pipt.untan.ac.id paling lambat pada tanggal yang tertera di pamflet.

\section{KESIMPULAN}

\section{Simpulan}

Berdasarkan hasil penelitian yang telah dilaksanakan, dapat disimpulkan secara umum bahwa pola dialog pembelajaran yang terbentuk pada materi fluida statis melalui Transcript Based Lesson Analysis (TBLA) 
di SMA Negeri 3 Pontianak adalah pola komunikasi dua arah dan pola komunikasi tiga arah. Adapun secara khusus dapat dipaparkan sebagai berikut : 1) Pola dialog pembelajaran secara klasikal yang terbentuk pada materi fluida statis melalui Transcript Based Lesson Analysis (TBLA) pada siklus 1 yaitu pola komunikasi dua arah. Hal ini karena adanya timbal balik antara guru dan peserta didik. Hal ini juga dibuktikan dari data hasil persentase rata-rata ucapan guru sebesar $7,70 \%$ dan persentase rata-rata ucapan peserta didik sebesar 7,70\%. Ini menunjukkan bahwa adanya keseimbangan antara guru dan peserta didik. Hal ini berarti guru dan peserta didik sama-sama aktif. Sedangkan pada siklus 2 secara klasikal pola dialog yang terbentuk adalah pola komunikasi dua arah. Hal ini juga dibuktikan dari data hasil persentase ratarata ucapan guru sebesar 8,34\% dan persentase rata-rata ucapan peserta didik sebesar 8,33\%. Ini menunjukkan bahwa adanya keseimbangan antara guru dan peserta didik. Hal ini berarti guru dan peserta didik sama-sama aktif dan terjadi hubungan timbal balik. Selain itu, pada siklus 2 juga terdapat pola komunikasi tiga arah pada menit ke-20. Hal ini karena adanya timbal balik antara guru dan peserta didik, serta antara peserta didik dengan peserta didik juga terjadi interaksi. Ini juga dibuktikan dari data hasil persentase ucapan guru sebesar $1,13 \%$ dan persentase ucapan peserta didik sebesar $1,74 \%$. Hal ini menunjukkan bahwa adanya hubungan timbal balik antara guru dan peserta didik, namun peserta didik cenderung lebih aktif. Sehingga peserta didik lebih banyak berbicara dibandingkan guru. Hal ini karena, peserta didik saling berargumen antara satu dengan yang lainnya.

\section{Saran}

Berdasarkan hasil penelitian ini, terdapat beberapa saran dan masukan untuk pelaksanaan penelitian yang akan datang, antara lain : 1) Sebaiknya dilakukan penelitian secara luring (tatap muka) agar terhindar dari masalah jaringan maupun media pembelajaran yang digunakan, sehingga penelitian dapat berjalan secara maksimal. 2) Analisis menggunakan Transcript Based Lesson Analysis (TBLA) ini dapat dijadikan metode untuk guru menganalisis pembelajaran di dalam kelas. Karena metode analisis ini memuat data yang valid yaitu berupa ucapan guru dan peserta didik selama pembelajaran berlangsung. Sehingga guru dapat membuat pembelajaran yang lebih efektif serta lebih meningkatkan mutu pembelajaran. 3) Sebaiknya guru bisa menerapkan pembelajaran lesson study karena dapat membuat peserta didik menjadi lebih aktif dan bersemangat dalam belajar.

\section{UCAPAN TERIMA KASIH}

Terima kasih penulis ucapkan kepada Ibu Dr. Haratua Tiur Maria S, M.Pd dan Ibu Erwina Oktavianty, M.Pd yang telah membimbing saya, , kepada pihak FKIP Untan dan SMA Negeri 3 yang telah memberi kesempatan kepada saya sehingga penelitian dapat terlaksana serta semua pihak yang telah membantu saya dalam melaksanakan penelitian ini.

\section{DAFTAR PUSTAKA}

Amintarti, Sri, dkk. (2020). Penerapan Transcript Based Lesson Analysis (TBLA) Sebagai Upaya Peningkatan Pembelajaran Kimia di SMA Negeri 7 Banjarmasin. Laporan Penelitian.

Djamarah, Syaiful Bahri. (2014). Guru dan Anak Didik dalam Interaksi Edukatif. Jakarta : PT Rineka Cipta.

Giancoli, Douglas C. (2001). Fisika Jilid 1 Edisi 5. Jakarta : Erlangga.

Hajar, Maya Umi. (2019). Analisis Pola Dialog Pembelajaran IPA Menggunakan TBLA (Transcript Based Lesson Analysis) di Salah Satu SMP Kota Bandung. Tesis 
Huang, Rongin, Takahashi Akihiko \& Joao Pedro da Ponte. (2019). Theory and Practice of Lesson Study in Mathematics.

Lisa, Ariesta \& Purwadi. (2018). Analisis Interaksi Guru dan Siswa dalam Pembelajaran Bahasa Indonesia di Kelas VII SMP Negeri 15 Kota Bengkulu. Jurnal Ilmiah Korpus, Vol 11 No. III.

Mahmudi, Ali. (2006). Pembelajaran Kolaboratif. (online). (https://core.ac.uk/download/pdf/335 09782. pdf?repositoryId=335).

Mercer, N \& Littleton, K. (2007). Dialogue and The Development of Childrens Thinking. New York : Routledge.

Mutiani, Warmansyah, Syaharuddin \& Susanto. (2020). Penerapan Transcript Based Lesson Analysis (TBLA) Sebagai Upaya Peningkatan Pembelajaran Sejarah di SMA Negeri 7 Banjarmasin. Laporan Penelitian.

Nurhayati, Agustine. (2015). Kekuasaan Dalam Bahasa (Analisis Percakapan Melalui Klasifikasi Tindak Tutur). (online).(

https://jurnal.uns.ac.id/prosidingprasa sti/article/view/77).

Peraturan Pemerintah Nomor 19 Tahun 2005 tentang Standar Nasional Pendidikan. (2019).

(online) (https://www.jogloabang.com/pendid ikan/pp-19-2005-standar-nasionalpendidikan).

Pratiwi, Riza Rahma, dkk. (2016). Upaya Peningkatan Keaktifan Belajar Siswa Melalui Implementasi Model Pembelajaran Kooperatif Tipe Teams Games Tournament (TGT) Berbantuan Pohon Pintar. Jurnal "Tata Arta" UNS, Vol. 2, No. 3, hlm.
1-10. (online). Primadiati, Ika Dewi \& D.Djukri. (2017). Pengaruh Model Collaborative Learning Terhadap Peningkatan Motivasi dan Hasil Belajar IPA Siswa Kelas IV SD. Jurnal Prima Edukasia, 5(1). (online).(

https://journal.uny.ac.id/index.php/jp e/article/view/7712/pdf).

Raharjo, Kurniawan Budi. (2013). Model Pembelajaran Kolaborasi (Collaborative Learning). (online) (diakses pada 25 agustus 2020). (https://kurniawanbudi04.word press.com/2013/05/27/collaborativelearning/)

Rahayu, Dea Santika. (2019). Analisis Pola Konstruksi Pengetahuan Siswa Dalam Pembelajaran IPA Pada Materi Gelombang Menggunakan TBLA (Transcript Based Lesson Analysis) di Salah Satu SMP Kota Bandung. Tesis.

Saito, dkk. (2006). Development of schoolbased in-service training under the Indonesian Mathematics and Science Teacher Education Project. Jurnal : Vol. 9, Number. 1.

Saptani, Parli. (2015). Tidak Tutur dalam Wacana Kelas VB SD Negeri 62 Kota Bengkulu Tahun Pelajaran 2012/2013. Jurnal : Vol. 1, No. 2.

Sucilestari, Ramdhani \& Arizona, Kurniawan. (2019). Kelas Inspirasi Berbasis Media Real Melalui Pendekatan Lesson Study. Jurnal Pengabdian Masyarakat, 15 (1).

Supriatna, Asep. (2018). Kegiatan Lesson Study Sebagi Upaya Guru untuk Menemukan Pembelajaran yang Memenuhi Keperluan Anak Hidup pada Zamannya (Era Revolusi Industri 4.0). FMIPA UNIMUS. Seminar Nasional Edusainstek. 